\title{
PENGARUH KOMBINASI SITOKININ DAN GIBBERELIN TERHADAP PEMANJANGAN TUNAS JAMBU METE (Anacardium Occidentale L.) SECARA IN VITRO
}

\author{
Febrina Ariyanti' ${ }^{1}$, Christiani Tumilisar ${ }^{1}$, Rossa Yunita ${ }^{2}$ \\ ${ }^{1}$ Program Studi Biologi FMIPA Universitas Negeri Jakarta, Indonesia. ${ }^{2}$ Besar Penelitian dan Pengembangan \\ Bioteknologi dan Sumberdaya Genetik Pertanian (BB-BIOGEN), Indonesia \\ Email: ariyantifebrina@gmail.com
}

\begin{abstract}
Cashew (Anacardium occidentale L.) is a plant with high economic value. Conventional propagation of this plant still has obstacles, so try to use an alternative techniques using tissue culture. One of the factors that determine the success of tissue culture techniques is the type and concentration of growth regulators is used. Growth regulator which have effect on shoot elongation is a cytokinin and gibberellins so need research to investigate the influence of combination cytokinin and gibberelin on in vitro shoot elongation of cashew. This research was conducted at BB-Biogen, Bogor on JuneNovember 2010. The method in this research is to design experimental method of research using completely randomized design. This result is cytokinin could increase the length of shoots and quantity of shoots very well. Cytokinin could increase length of shoot until $4 \mathrm{~cm}$ and quantity of shoot is 5 . For shoot length, the most effective cytokinin is zeatin $5 \mathrm{mg} / \mathrm{l}$.
\end{abstract}

Key words: Anacardium occidentale L., cytokinin, elongation of shoots, gibberelin

\section{PENDAHULUAN}

Tanaman jambu mete (Anacardium occidentale L.) merupakan tanaman dengan nilai ekonomi tinggi. Perbanyakan tanaman jambu mete secara konvensional dapat dilakukan dengan cara vegetatif maupun generatif. Secara generatif menggunakan butir-butir gelendong, akan tetapi butir gelendong yang digunakan sebagai benih akan menghasilkan pohon dengan sifat genetik yang tidak sama dengan induknya (Zaubin dan Suryadi, 2003). Perbanyakan vegetatif dilakukan dengan menggunakan bibit hasil sambung pucuk (grafting), tetapi pertumbuhannya lebih aktif di bagian pucuk sehingga kanopi cepat rimbun membentuk setengah bola dan cabang relatif pendek sehingga hasil produksinya rendah (Hadad, Daras, \& Wahyudi, 2007)

Alternatif lain dalam perbanyakan tanaman jambu mete yang sedang dikembangkan yaitu melalui teknik kultur jaringan. Keuntungan mempergunakan teknik kultur jaringan adalah ukuran eksplan yang dipergunakan kecil, dapat dipergunakan untuk memperbanyak tanaman yang sulit diperbanyak, serta tidak tergantung oleh cuaca (George, Hall, \& Klerk, 2008), dengan cara ini perbanyakan jambu mete diharapkan dapat menghasilkan bibit yang bermutu baik dan dalam jumlah yang banyak.

Salah satu faktor yang menentukan keberhasilan perbanyakan melalui kultur jaringan adalah jenis dan konsentrasi zat pengatur tumbuh (ZPT) yang digunakan. Penelitian ini merupakan kegiatan lanjutan dari kegiatan induksi dan multiplikasi tunas adventif tanaman jambu mete secara in vitro yang telah dilakukan oleh Tumilisar 
danYunita (2009). Berdasarkan kegiatan tersebut didapatkan media untuk induksi tunas yaitu media Murashige dan Skoog (MS) + BA (Benzil adenin) 0,7 mg/l. Media optimal pada tahap multiplikasi yaitu media MS dengan penambahan thidiazuron $0,5 \mathrm{mg} / \mathrm{l}$ dan zeatin $1 \mathrm{mg} / \mathrm{l}$ (Tumilisar dan Yunita, 2009). Setelah tahap multiplikasi diharapkan tunas akan mengalami pemanjangan dengan demikian terjadi pertambahan ukuran tunas sebelum induksi akar, oleh karena itu perlu dicari jenis dan konsentrasi zat pengatur tumbuh yang tepat untuk dapat merangsang pemanjangan tunas. Pemanjangan tunas disertai dengan membukanya primordia daun menjadi helaian daun. Terkadang pada tahap pemanjangan tunas diikuti pula dengan multiplikasi tunas, sehingga pada penelitian ini selain diamati panjang tunas juga diamati pertambahan jumlah daun dan tunas.

Pada tahapan pemanjangan tunas, terdapat dua zat pengatur tumbuh yang mempengaruhi yaitu sitokinin dan gibberelin, oleh karena itu perlu dilakukan penelitian yang bertujuan untuk mengetahui pengaruh kombinasi sitokinin dan gibberelin terhadap pemanjangan tunas jambu mete secara in vitro.

Penelitian ini bertujuan untuk menentukan kombinasi dan konsentrasi zat pengatur tumbuh yang paling efektif terhadap pemanjangan tunas jambu mete dengan cara mengukur pertambahan panjang tunas, menghitung pertambahan jumlah tunas dan daun, serta mendeskripsikan kondisi visual eksplan (warna, dan ada atau tidaknya gejala nekrosis).

\section{METODE PENELITIAN}

Penelitian ini dilakukan di Laboratorium Biologi Sel Dan Jaringan Balai Besar Penelitian dan Pengembangan Bioteknologi dan Sumberdaya Genetik Pertanian (BB-BIOGEN) Jl. Tentara Pelajar No. 3A, Bogor yang dimulai dari Bulan Juni sampai dengan November 2010

Metode penelitian ini mempergunakan metode eksperimen, dengan panjang tunas jambu mete sebagai variabel terikat, sedangkan variabel bebasnya adalah kombinasi dan konsentrasi ZPT. Percobaan disusun dalam rancangan acak lengkap faktorial yang terdiri dari 2 faktor dan 5 ulangan. Faktor pertama yaitu kombinasi ZPT yang terdiri dari gibberelin + zeatin dan gibberelin + BAP, sedangkan faktor kedua adalah konsentrasi zat pengatur tumbuh. Semua perlakuan dikulturkan pada media dasar Murashige Skoog.

Alat yang digunakan adalah laminar air flow, hot plate, $\mathrm{pH}$ meter, magnetic-stirrer, motor plate, autoklaf model HL 36, oven Wtb binder type, timbangan, alat tanam dan kamera digital Nikon D3000. Bahan tanam yang digunakan adalah eksplan tunas tanaman jambu mete varietas Balakrisnan (B-02), berukuran \pm 1 , bahan pemadat berupa agar, dan gula pasir. Zat pengatur tumbuh yaitu zeatin, BAP, dan gibberelin. Eksplan dikulturkan pada media MS yang

Tabel 1. Desain perlakuan zat pengatur tumbuh

\begin{tabular}{|c|c|c|c|c|}
\hline \multicolumn{5}{|c|}{ Konsentrasi (mg/l) } \\
\hline \multicolumn{5}{|c|}{ Gibberelin $\left(\mathrm{GA}_{3}\right)$} \\
\hline & & 0,3 & 0,5 & 0,7 \\
\hline \multicolumn{5}{|c|}{ Sitokinin } \\
\hline \multirow[t]{3}{*}{$\overline{\mathrm{BAP}}$} & 1 & $0,3: 1$ & $0,5: 1$ & $0,7: 1$ \\
\hline & 3 & $0,3: 3$ & $0,5: 3$ & $0,7: 3$ \\
\hline & 5 & $0,3: 5$ & $0,5: 5$ & $0,7: 5$ \\
\hline \multirow[t]{3}{*}{ Zeatin } & 1 & $0,3: 1$ & $0,5: 1$ & $0,7: 1$ \\
\hline & 3 & $0,3: 3$ & $0,5: 3$ & $0,7: 3$ \\
\hline & 5 & $0,3: 5$ & $0,5: 5$ & $0,7: 5$ \\
\hline
\end{tabular}


telah ditambahkan ZPT. Eksplan diinkubasi selama 6 minggu pengamatan.

\section{HASIL}

\section{PERTAMBAHAN PANJANG TUNAS}

Pengaruh kombinasi sitokinin dan gibberelin beserta konsentrasinya terhadap perubahan panjang tunas dapat dilihat pada Tabel 2. Rata-rata pertambahan panjang tunas tertinggi pada umur 6 minggu terdapat pada perlakuan zeatin $5 \mathrm{mg} / \mathrm{l}+\mathrm{GA}_{3} 0,7 \mathrm{mg} / \mathrm{l}$ yaitu $1,80 \pm 0,25$, untuk grafik perlakuan $\mathrm{BAP}+\mathrm{GA}_{3}$ dan zeatin $+\mathrm{GA}_{3}$ terbaik dapat dilihat pada Gambar 1.

Tabel 2. Rata-rata hasil pertambahan panjang tunas jambu mete

\begin{tabular}{llll}
\hline & $\mathrm{GA}_{3}(\mathrm{mg} / \mathrm{l})$ & \multicolumn{3}{l}{ Pertambahan Panjang tunas Jambu Mete } \\
\cline { 3 - 4 } Sitokinin $(\mathrm{mg} / \mathrm{l})$ & 0,3 & 0,5 & 0,7 \\
\hline BAP 1 & $1,36 \pm 0,11$ & $1,44 \pm 0,09$ & $1,34 \pm 0,19$ \\
BAP 3 & $1,32 \pm 0,24$ & $1,46 \pm 0,17$ & $1,36 \pm 0,29$ \\
BAP 5 & $1,44 \pm 0,09$ & $1,46 \pm 0,19$ & $1,66 \pm 0,25$ \\
Zeatin 1 & $1,52 \pm 0,19$ & $1,50 \pm 0,10$ & $1,46 \pm 0,22$ \\
Zeatin 3 & $1,34 \pm 0,17$ & $1,62 \pm 0,22$ & $1,62 \pm 0,18$ \\
Zeatin 5 & $1,62 \pm 0,45$ & $1,42 \pm 0,16$ & $1,80 \pm 0,25$ \\
Kontrol & $1,30 \pm 0,30$ & & \\
\hline
\end{tabular}

Zeatin $5 \mathrm{mg} / 1+\mathrm{GA}_{3}$ 0,7 mg/l memperlihatkan hasil lebih baik dibandingkan dengan perlakuan BAP $5 \mathrm{mg} / 1$ $+\mathrm{GA}_{3}$ 0,7 mg/l. Grafik tersebut menunjukkan bahwa ZPT paling berpengaruh adalah zeatin dengan konsentrasi tertinggi. Berdasarkan Gambar 1 diketahui bahwa pertambahan panjang tunas paling tinggi terjadi pada minggu kedua yaitu sebesar $0,26 \mathrm{~cm}$, hal ini diduga disebabkan eksplan baru dapat beradaptasi, sehingga baru pada waktu tersebut terjadi penyerapan nutrisi yang didapat dari media dengan optimal.

Data rata-rata pertambahan panjang tunas mete selanjutnya diuji dengan menggunakan ANAVA dua arah. Hasil pengujian tersebut menunjukkan bahwa zat pengatur tumbuh berupa zeatin dan BAP signifikan karena memiliki nilai signifikansi kurang dari 0,05 yaitu 0,029 < 0,05, artinya ZPT zeatin dan BAP memberikan pengaruh terhadap pertambahan panjang tunas jambu mete, sedangkan ZPT GA memiliki nilai signifikansi lebih dari 0,05 yaitu 0,13>0,05 artinya ZPT GA 3 tidak memberikan pengaruh terhadap pemanjangan tunas jambu mete, hal ini diduga dikarenakan konsentrasi $\mathrm{GA}_{3}$ yang dipergunakan belum tepat sehingga zat pengatur tumbuh ini tidak terlihat pengaruhnya terhadap pemanjangan tunas, akan tetapi berdasarkan Gambar 2a dan $2 \mathrm{~b}$ terlihat bahwa daun jambu mete mengalami pertambahan luas, hal ini disebabkan $\mathrm{GA}_{3}$ dapat memperbesar luas daun dari berbagai jenis tanaman (Wattimena, 1988).

Selanjutnya dilakukan uji lanjutan berupa uji Duncan untuk kelompok zat pengatur tumbuh yang berpengaruh terhadap pemanjangan tunas yaitu sitokinin (lihat Tabel 3), dikarenakan pada uji ANAVA hanya ZPT sitokinin yang memiliki nilai probabilitas $<0,05$ yaitu 0,029. Uji ini dilakukan untuk mengetahui perbedaan pengaruh antara kelompok perlakuan. Berdasarkan uji Duncan diketahui Zeatin $5 \mathrm{mg} / \mathrm{l}$ memperlihatkan pengaruh yang berbeda dengan BAP $1 \mathrm{mg} / \mathrm{l}$ dan BAP $3 \mathrm{mg} / \mathrm{l}$. Zeatin $1 \mathrm{mg} / \mathrm{l}$, BAP $5 \mathrm{mg} / \mathrm{l}$, dan zeatin $3 \mathrm{mg} / 1$ tidak memiliki 
pengaruh yang berbeda terhadap pemanjangan tunas jambu mete secara in vitro. Zeatin $5 \mathrm{mg} / \mathrm{lmemiliki}$ pengaruh paling berbeda dengan nilai 0,6133 .

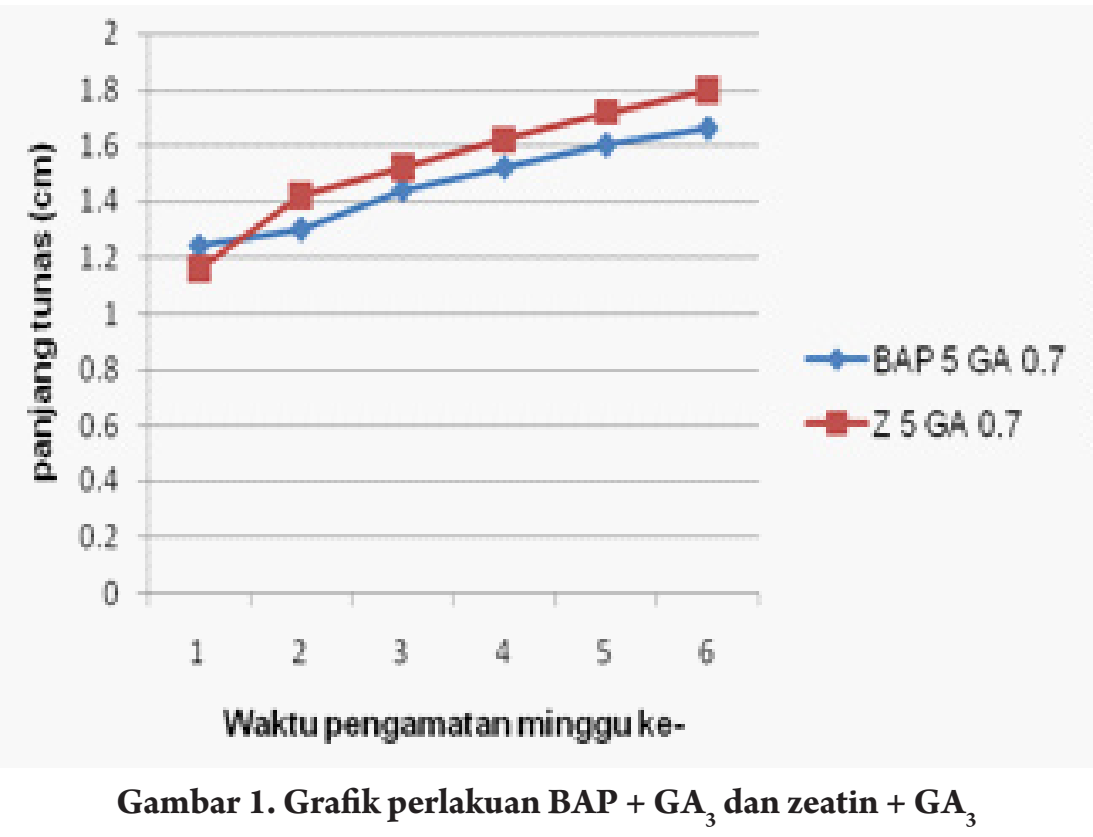

Berdasarkan penelitian ini diketahui juga bahwa apabila BAP dan zeatin digunakan tidak berkombinasi dengan $\mathrm{GA}_{3}$ justru memberikan hasil yang paling baik. Hal ini serupa dengan penelitian terhadap tumbuhan Wrightia tinctoria (Purohit, dan Kukda, 2004) dimana BAP memberikan hasil baik apabila tidak dipergunakan bersama-sama dengan ZPT yang lain.

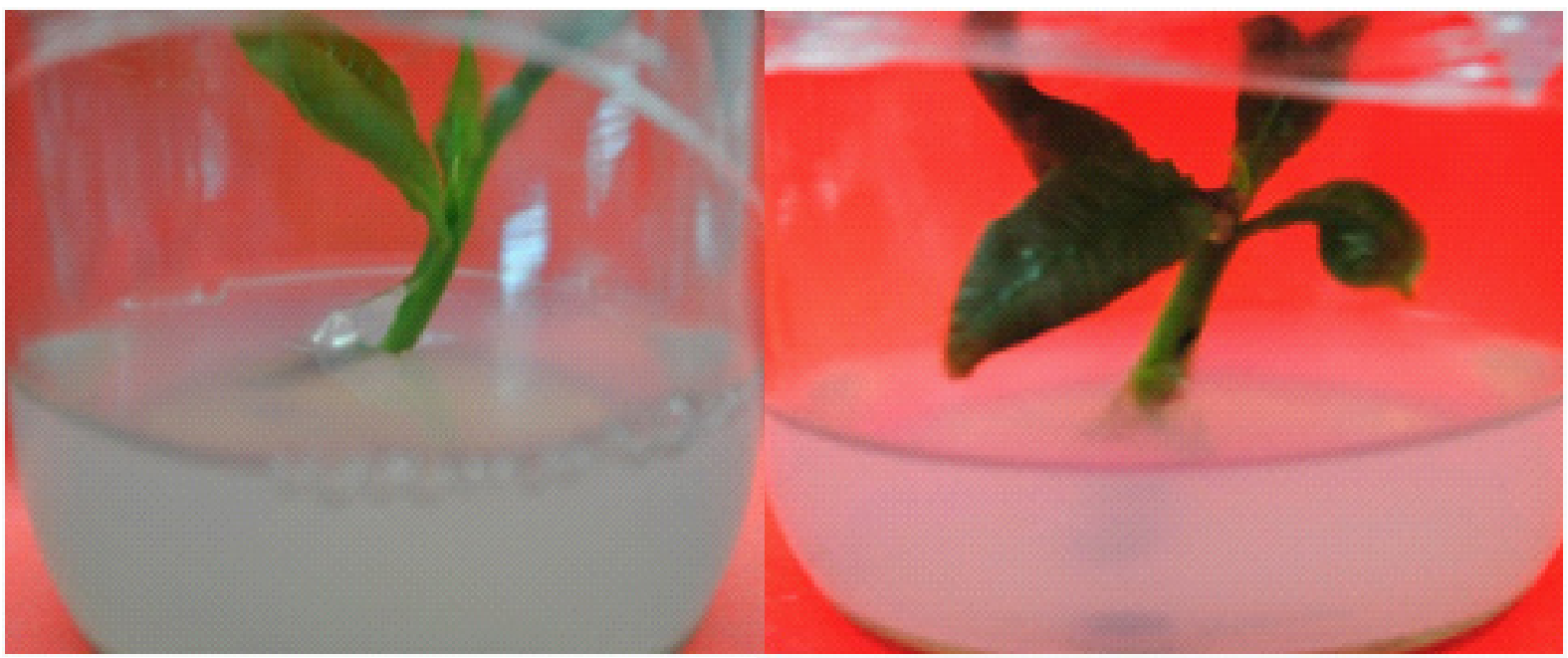

Gambar 2. (a). Eksplan perlakuan Z $1 \mathrm{mg} / 1+\mathrm{GA}_{3} 0,5 \mathrm{mg} / 1 \mathrm{minggu} 1(\mathrm{~b})$. Eksplan perlakuan $\mathrm{Z} 1 \mathrm{mg} / 1+\mathrm{GA}_{3}$ $0,5 \mathrm{mg} / 1$ minggu 5

Zeatin memberikan hasil lebih baik dibandingkan dengan BAP dikarenakan zeatin adalah sitokinin alami, sedangkan BAP adalah sitokinin sintetik. Menurut George dan Sherrington (1984) pertumbuhan dan morfogenesis secara in vitro dipengaruhi oleh interaksi dan keseimbangan antar ketersediaan zat pengatur tumbuh di dalam 
media dan zat pengatur tumbuh yang secara alami terdapat pada sel yang dikulturkan. Selain untuk mempengaruhi mekanisme selular, banyak zat pengatur tumbuh sintesis secara nyata memodofikasi tingkat kandungan zat pengatur tumbuh endogen, karena zeatin adalah ZPT alami, zeatin tidak mempengaruhi kadar ZPT alami yang terdapat di dalam sel. Hal ini serupa dengan penelitian yang dilakukan oleh Ellis, et al. (1991) menyatakan zeatin lebih efektif dibandingkan dengan BA pada pertumbuhan tunas Picea glauca

Tabel 3. Uji Duncan untuk zat pengatur tumbuh sitokinin

\begin{tabular}{llll}
\hline \multirow{2}{*}{ ZPT sitokinin } & $\mathrm{N}$ & \multicolumn{2}{l}{ Subset } \\
\cline { 3 - 4 } & & 1 & 2 \\
\hline BAP $1 \mathrm{mg} / 1$ & 15 & $0,38^{*}$ & \\
BAP $3 \mathrm{mg} / 1$ & 15 & $0,38^{*}$ & \\
Zeatin $1 \mathrm{mg} / 1$ & 15 & 0,49 & 0,49 \\
BAP $5 \mathrm{mg} / 1$ & 15 & 0,52 & 0,52 \\
Zeatin $3 \mathrm{mg} / 1$ & 15 & 0,55 & 0,55 \\
Zeatin $5 \mathrm{mg} / 1$ & 15 & & $0,61^{*}$ \\
\hline
\end{tabular}

Pada pengamatan siklus sel terhadap tanaman Nicotiana tabacum cv. Yellow-2 (BY-2), sitokinin yang paling terlihat keberadaannya adalah zeatin dengan konsentrasi tertinggi terlihat pada awal fase G1, akhir G1 menuju fase S, pertengahan atau akhir fase S, dan Transisi fase G2 atau M (Davies, 2004). George (1993) mengatakan bahwa fase G1 adalah fase meningkatnya kuantitas organela dan meningkatnya volume sitoplasma. Setelah fase G1, maka sel akan segera memasuki fase $S$. Fase $S$ adalah saat terjadinya sintesa DNA yang menghasilkan replikasi DNA. Fase $S$ diikuti oleh fase G2 dimana sel mempersiapkan diri untuk mitosis, sedangkan fase $\mathrm{M}$ adalah fase mitosis dimana terjadi pembelahan inti dan pemisahan sitoplasma.

Pada penelitian ini terdapat tunas yang mengalami gangguan dalam pertumbuhannya disebabkan beberapa hal, diantaranya masalah pencoklatan (browning) seperti terlihat pada Gambar 3. Masalah pencoklatan disebabkan adanya oksidasi senyawa fenolik oleh polyphenol oxidase (PPO) yang dapat menyebabkan perubahan warna eksplan menjadi coklat. PPO ditemukan di kloroplas, sitoplasma, serta diantara plasmalema dan dinding sel (Obukowicz \& Kennedy, 1981 dalam Nguyen, Ketsa, \& Van Doorn, 2003), sedangkan senyawa fenolik terdapat di vakuola (Va' mosVigya'zo, 1981 dalam Nguyen, Ketsa, \& Van Doorn, 2003). Jika vakuola mengalami kerusakan maka fenolik yang terdapat di vakuola akan bereaksi dengan PPO, hal ini menyebabkan terjadinya perubahan warna menjadi coklat (Nguyen, Ketsa, \& Van Doorn, 2003).

\section{PERTAMBAHAN JUMLAH TUNAS}

Pengaruh kombinasi sitokinin dan gibberelin beserta konsentrasinya terhadap perubahan jumlah tunas dapat dilihat pada Tabel 4. Rata-rata pertambahan jumlah tunas tertinggi terdapat pada perlakuan zeatin $3 \mathrm{mg} / 1$ dan $\mathrm{GA}_{3} 0,5 \mathrm{mg} /$ yaitu $1,00 \pm 0,71$, sedangkan rata-rata pertambahan jumlah tunas terendah pada perlakuan BAP $1 \mathrm{mg} / 1$ + GA $30,7 \mathrm{mg} / \mathrm{l}, \mathrm{MS}+\mathrm{BAP} 3 \mathrm{mg} / \mathrm{l}+\mathrm{GA} 3$ 0,3 mg/l, BAP $5 \mathrm{mg} / \mathrm{l}+\mathrm{GA}_{3}$ 0,7 mg/l, serta perlakuan zeatin $5 \mathrm{mg} / \mathrm{l}$ + $\mathrm{GA}_{3} 0,5 \mathrm{mg} / \mathrm{l}$, zeatin $5 \mathrm{mg} / \mathrm{l}+\mathrm{GA} 30,7 \mathrm{mg} / \mathrm{l}$ yaitu $\quad 0,00 \pm 0,00$. Untuk grafik perlakuan BAP + GA dengan hasil terbaik terhadap rata-rata jumlah tunas dapat dilihat pada gambar 4, sedangkan grafik perlakuan zeatin + GA3 dengan hasil terbaik terhadap rata-rata jumlah tunas dapat dilihat pada Gambar 5.

Berdasarkan Gambar 4 dan 5 diketahui bahwa pembentukan tunas paling banyak pada perlakuan BAP + 
$\mathrm{GA}_{3}$ terjadi pada minggu pertama perlakuan BAP $5 \mathrm{mg} / \mathrm{l}+\mathrm{GA}_{3} 0,3 \mathrm{mg} / \mathrm{l}$, sedangkan pada perlakuan zeatin $+\mathrm{GA}_{3}$ pembentukan tunas paling banyak terjadi pada minggu keenam perlakuan zeatin $3 \mathrm{mg} / 1+\mathrm{GA}_{3} 0,5 \mathrm{mg} / \mathrm{l}$. Pembentukan tunas tercepat ada pada perlakuan $\mathrm{BAP}+\mathrm{GA}_{3}$, hal ini diduga dikarenakan eksplan telah dapat beradapatasi dengan cepat sehingga pada minggu pertama, eksplan telah dapat menyerap nutrisi dari media pertumbuhan dengan optimal. Perlakuan yang tidak mengalami pertambahan jumlah tunas diduga disebabkan daya meristematis tanaman yang rendah serta tingginya tingkat oksidasi fenol (Mariska \& Purnamaningsih, 1997).

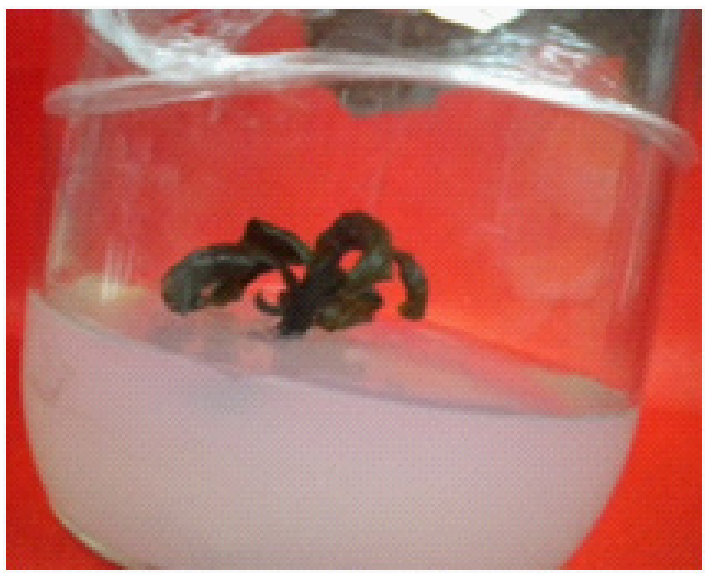

Gambar 3. Tunas yang mengalami pencoklatan pada perlakuan perlakuan $\mathrm{BAP}_{5 \mathrm{mg} / 1}+\mathbf{G A}_{30,7 \mathrm{mg} / 1}$

Pada BAP $3 \mathrm{mg} / 1+\mathrm{GA}_{3}$ 0,5 mg/l, terjadi lonjakan jumlah tunas diduga dikarenakan eksplan baru dapat menyerap nutrisi dengan optimal pada minggu keenam, sehingga kemungkinan grafik pertumbuhan eksplan masih dapat bergerak naik pada minggu berikutnya.

\begin{tabular}{llll}
\hline \multicolumn{4}{l}{ Tabel 4. Rata-rata hasil pertambahan jumlah tunas jambu mete pada umur $\mathbf{6}$ minggu } \\
\hline \multirow{2}{*}{ Sitokinin } & $\mathrm{GA}_{3}$ & \multicolumn{1}{l}{ Pertambahan Jumlah Tunas Jambu Mete } & \\
\cline { 2 - 4 } & $0,3 \mathrm{mg} / 1$ & $0,5 \mathrm{mg} / 1$ & $0,7 \mathrm{mg} / 1$ \\
\hline BAP $1 \mathrm{mg} / 1$ & $0,20 \pm 0,45$ & $0,40 \pm 0,55$ & $0,00 \pm 0,00$ \\
BAP $3 \mathrm{mg} / 1$ & $0,00 \pm 0,00$ & $0,40 \pm 0,55$ & $0,40 \pm 0,55$ \\
BAP $5 \mathrm{mg} / 1$ & $0,40 \pm 0,55$ & $0,20 \pm 0,45$ & $0,00 \pm 0,00$ \\
Zeatin $1 \mathrm{mg} / 1$ & $0,40 \pm 0,55$ & $0,20 \pm 0,45$ & $0,80 \pm 0,45$ \\
Zeatin $3 \mathrm{mg} / 1$ & $0,40 \pm 0,55$ & $1,00 \pm 0,71$ & $0,60 \pm 0,89$ \\
Zeatin $5 \mathrm{mg} / 1$ & $0,60 \pm 0,55$ & $0,00 \pm 0,00$ & $0,00 \pm 0,00$ \\
\hline Kontrol & $0,00 \pm 0,00$ & \\
\hline
\end{tabular}

Pengaruh kombinasi sitokinin dan gibberelin terhadap pertambahan jumlah tunas diketahui dengan melakukan uji Kruskal Wallis, didapatkan hasil ZPT berupa zeatin dan BAP memiliki nilai signifikansi kurang dari 0,05 yaitu $0,021<0,05$ artinya terdapat pengaruh, sedangkan ZPT berupa $\mathrm{GA}_{3}$ memiliki nilai signifikansi lebih dari 0,05 yaitu 0,407 >0,05 artinya $\mathrm{GA}_{3}$ tidak memberikan pengaruh terhadap pertambahan jumlah tunas.

Sitokinin memberikan pengaruh terhadap pertambahan tunas dikarenakan selain untuk menstimulasi pembelahan sel, sitokinin dapat menghambat pembentukan akar dan berperan pada proses proliferasi tunas (George \& Sherrington, 1984). Hal ini sesuai dengan penelitian pada almond (Amygdalus communis L. cv. Yaltsinki) dengan eksplan berupa tunas apikal dari tanaman dewasa (berusia 7 tahun) diketahui bahwa sitokinin BAP diperlukan 
untuk multiplikasi tunas yang dikulturkan pada media MS (Akbas, et al., 2009). GA tidak berpengaruh terhadap multiplikasi tunas disebabkan $\mathrm{GA}_{3}$ berfungsi untuk morfogenesis, menghambat pembentukan akar, berperan dalam perkembangan embrio, dan diferensiasi sel (George, Hall, \& Klerk, 2008).

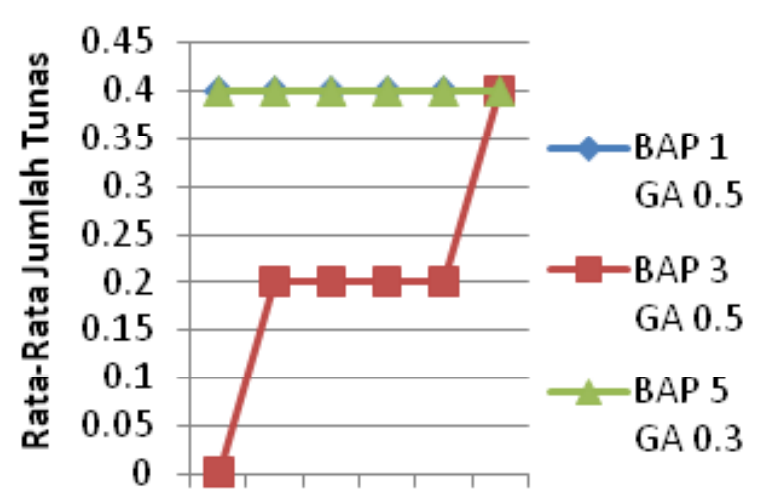

$\begin{array}{llllll}1 & 2 & 3 & 4 & 5 & 6\end{array}$

Waktu Pengamatan minggu ke-

Gambar 4. Grafik perlakuan BAP + GA terbaik terhadap jumlah tunas jambu mete umur 6 minggu

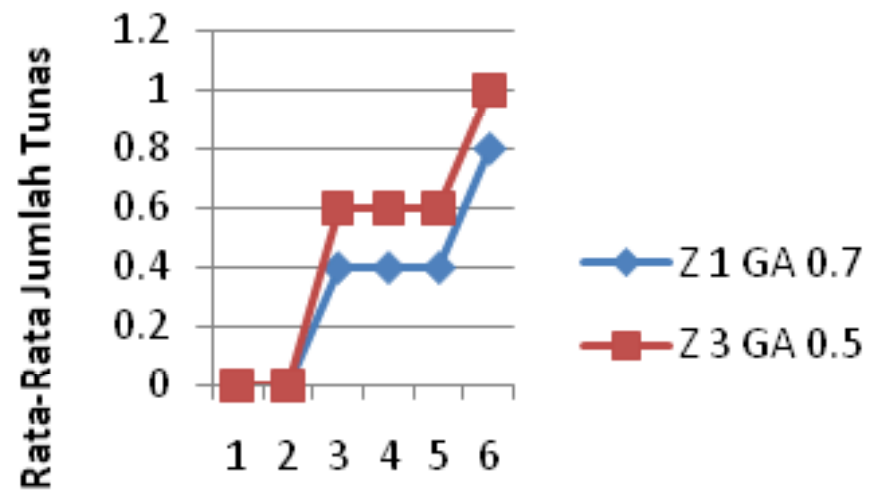

Waktu pengamatan minggu ke-

\section{PERTAMBAHAN JUMLAH DAUN}

Pengaruh kombinasi sitokinin dan gibberelin beserta konsentrasinya terhadap pertambahan jumlah daun dapat dilihat pada Tabel 5. Rata-rata pertambahan jumlah daun tertinggi pada umur 6 minggu terdapat pada zeatin 3 $\mathrm{mg} / \mathrm{l}+\mathrm{GA}_{3} 0,5 \mathrm{mg} / \mathrm{l}$, yaitu 1,20 \pm 0,84, dan terendah pada perlakuan BAP $3 \mathrm{mg} / 1+\mathrm{GA}_{3} 0,7 \mathrm{mg} / \mathrm{l}$, dan BAP $5 \mathrm{mg} / 1+$ GA3 $0,7 \mathrm{mg} / 1$ serta pada perlakuan zeatin $5 \mathrm{mg} / \mathrm{l}+\mathrm{GA}_{3} 0,5 \mathrm{mg} / \mathrm{l}$ yaitu $0,00 \pm 0,00$. Grafik perlakuan $\mathrm{BAP}+\mathrm{GA}_{3}$ dan zeatin+GA terbaik dapat dilihat pada Gambar 6.

Tabel 5. Rata-rata hasil pertambahan jumlah daun jambu mete pada umur 6 minggu

\begin{tabular}{llll} 
& $\mathrm{GA}_{3}$ & \multicolumn{3}{l}{ Pertambahan Jumlah Tunas Jambu Mete } \\
\cline { 2 - 4 } Sitokinin & $0,3 \mathrm{mg} / 1$ & $0,5 \mathrm{mg} / 1$ & $0,7 \mathrm{mg} / 1$ \\
\hline BAP 1 mg/l & $0,80 \pm 0,84$ & $0,40 \pm 0,55$ & $0,20 \pm 0,45$ \\
BAP 3 mg/l & $0,20 \pm 0,45$ & $0,40 \pm 0,55$ & $0,00 \pm 0,00$ \\
BAP 5 mg/1 & $0,40 \pm 0,55$ & $0,40 \pm 0,90$ & $0,00 \pm 0,00$ \\
Zeatin 1 mg/1 & $0,80 \pm 0,84$ & $0,20 \pm 0,45$ & $0,60 \pm 0,55$ \\
Zeatin 3 mg/1 & $0,40 \pm 0,55$ & $1,20 \pm 0,84$ & $0,40 \pm 0,55$ \\
Zeatin 5 mg/l & $0,40 \pm 0,55$ & $0,00 \pm 0,00$ & $0,40 \pm 0,90$ \\
Kontrol & $0,20 \pm 0,45$ & & \\
\hline
\end{tabular}

Gambar 6 memperlihatkan bahwa perlakuan zeatin $3 \mathrm{mg} / \mathrm{l}+\mathrm{GA}_{3} 0,5 \mathrm{mg} / \mathrm{l}$ lebih baik bila dibandingkan dengan BAP $1 \mathrm{mg} / \mathrm{l}+\mathrm{GA}_{3}$ 0,3 mg/l. Berdasarkan Tabel 5 diketahui bahwa semakin meningkat konsentrasi tidak memberikan hasil yang meningkat pula hal ini diduga konsentrasi ZPT yang diberikan belum tepat (Abidin, 1982). Untuk mengetahui ada atau tidaknya pengaruh kombinasi sitokinin dan gibberelin terhadap pertambahan jumlah daun, data diuji dengan menggunakan uji Kruskal Wallis, didapatkan hasil nilai signifikansi lebih dari 0,05 yaitu 0,24 $>0,05$ artinya tidak terdapat pengaruh ZPT terhadap pertambahan jumlah daun jambu mete secara in vitro. Hal ini diduga dikarenakan tunas belum mengalami diferensiasi. Tunas mengalami beberapa fase pertumbuhan yang diawali 
dengan pembelahan sel, pemanjangan, diferensiasi, dan maturasi. Diduga perkembangan sebagian besar tunas baru berlangsung pada tahap pemanjangan, belum memasuki tahap diferensiasi (Kozlowski, 1971).

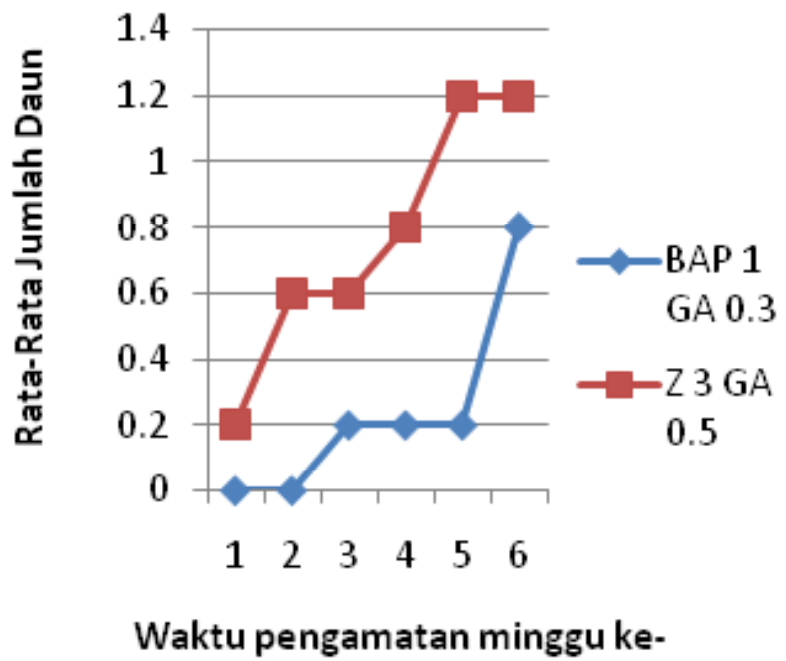

Gambar 6. Grafik perlakuan BAP + GA dan zeatin + GA terbaik terhadap pertambahan jumlah daun jambu mete pada umur 6 minggu

\section{VISUALISASI EKSPLAN}

Sebagian besar eskplan tetap berwarna hijau, tidak mengalami gejala pencoklatan (browning), dan nekrosis. Hal ini dikarenakan efek sitokin yang memperlambat proses penghancuran butir-butir klorofil dan menghambat proses penuaan pada daun (Wattimena, 1988), akan tetapi terdapat beberapa eksplan bagian daunnya mengalami gejala pencoklatan akibat oksidasi fenolik (Gambar 7b), dan gejala nekrosis atau kematian jaringan (Gambar 7c) setelah beberapa waktu setelah tanam. Beberapa tumbuhan terutama tumbuhan tropis memiliki kandungan fenol dalam konsentrasi tinggi yang akan teroksidasi ketika sel tumbuhan tersebut terluka, yang berakibat jaringan tumbuhan akan berwarna coklat atau hitam dan gagal untuk tumbuh (George, Hall, \& Klerk, 2008). Percobaan dengan berbagai senyawa fenolik eksogen menunjukkan bahwa senyawa fenolik menghambat pembelahan sel, pembesaran sel, pertumbuhan, dan perkecambahan biji (Wattimena, 1987).

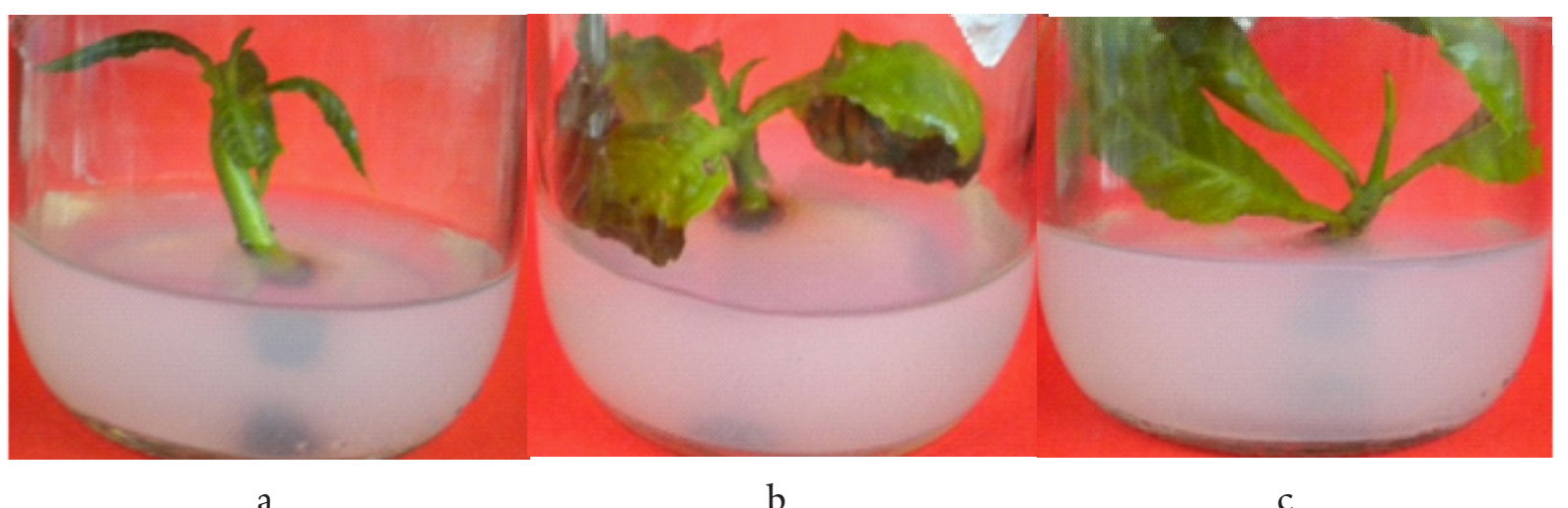

Gambar 7. (a) Perlakuan BAP 5 mg/1 GA 0,7 mg/1 minggu ke-5 dengan kondisi baik, (b) Perlakuan BAP 5 mg/1 GA3 0,7 mg/1 minggu ke-5 yang mencoklat, (c) Perlakuan BAP 5 mg/1 GA3 0,7 mg/1 minggu ke-5 yang mengalami nekrosis. 


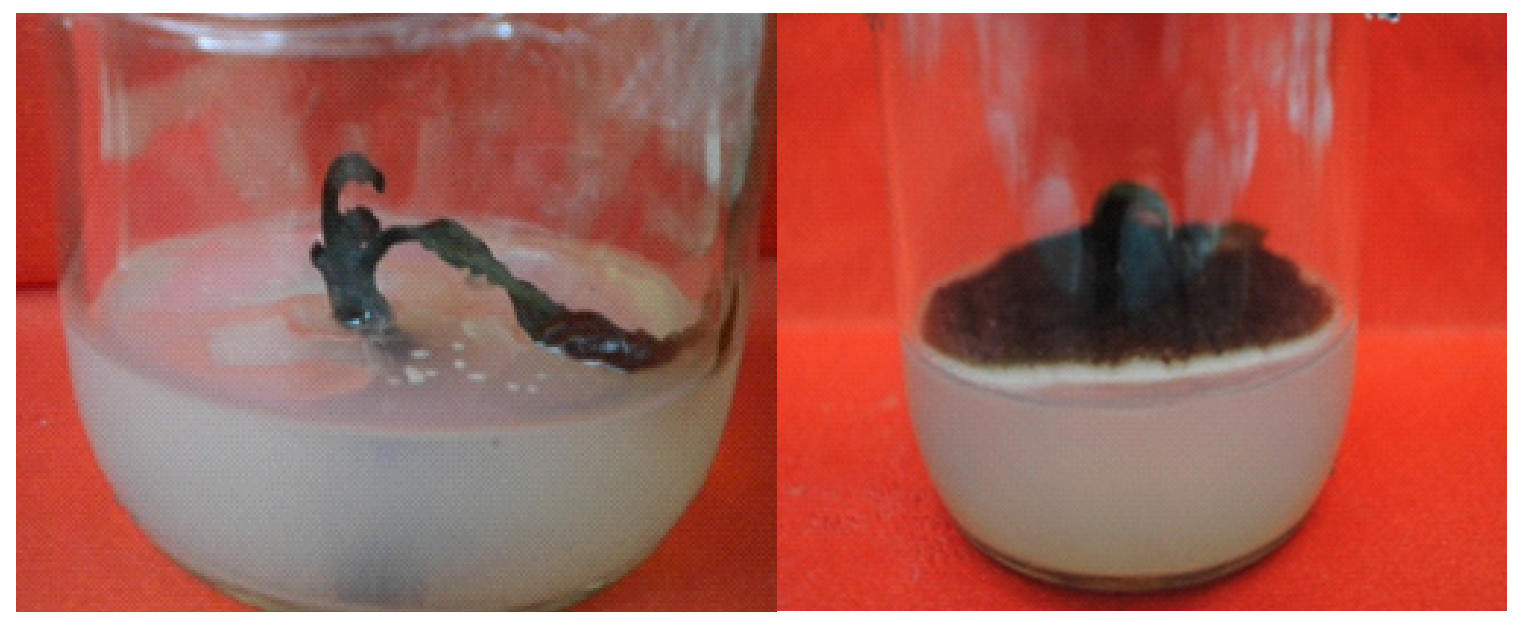

$\mathbf{a}$

b

Gambar 8. (a) Perlakuan BAP $1 \mathrm{mg} / 1+\mathrm{GA}_{3} 0,5 \mathrm{mg} / 1$ minggu ke-6 yang terkontaminasi bakteri , (b) Tunas kontrol minggu ke-5 terkontaminasi jamur

Bagian eksplan yang mengalami nekrosis, pada umumnya adalah daun yang telah tua hal ini sesuai dengan Wong (2006) yang mengatakan nekrosis merupakan peristiwa kematian jaringan yang disebabkan kekurangan nutrisi berupa nitrogen, fosfor, potassium, dan magnesium. Peristiwa ini pada umumnya terjadi di daun yang sudah tua, hal ini disebabkan nutrisi ini merupakan elemen bergerak yang dapat ditranslokasikan dari daun tua ke daun yang masih muda apabila nutrisi tidak cukup.

Selain itu beberapa eksplan mengalami kontaminasi. Kontaminasi yang terjadi disebabkan bakteri (Gambar 8a) ataupun jamur (Gambar 8b). Kontaminasi kemungkinan disebabkan tunas terkena kontaminan ketika pengukuran. Pengukuran dilakukan dengan cara mengeluarkan eksplan dari botol kultur, hal ini menyebabkan eksplan rentan terkontaminasi.

\section{KESIMPULAN}

1. Kombinasi sitokinin dan gibberelin beserta konsentrasinya secara statistik tidak berpengaruh terhadap pemanjangan tunas jambu mete (Anacardium occidentale $\mathrm{L}$.) secara in vitro, namun secara visual ukuran tunas paling tinggi ada pada perlakuan zeatin $5 \mathrm{mg} / \mathrm{l}+\mathrm{GA} 30,7 \mathrm{mg} / \mathrm{l}$.

2. Zeatin $5 \mathrm{mg} / \mathrm{l}$ paling berpengaruh terhadap pemanjangan tunas jambu mete secara in vitro.

3. Zat pengatur tumbuh berupa sitokinin berpengaruh terhadap pertambahan jumlah tunas.

4. Kombinasi sitokinin dan gibberelin beserta konsentrasinya tidak berpengaruh terhadap pertambahan jumlah daun

\section{DAFTAR PUSTAKA}

Abidin, Z. (1982). Dasar-Dasar Pengetahuan Tentang Zat Pengatur Tumbuh. Bandung: Penerbit angkasa.

Akbas, Filiz, C. Isikalan, S. Namli, dan B. Erol Ak. (2009). Effect of plant growth regulators on in vitro shoot multiplication of Amygdalus communis L. cv. Yaltsinki. African Journal of Biotechnology,Vol. 8 (22), pp. 6168-6174, 16 November, 2009

Davies, P. J (Ed). (2004). Plant Hormones, Biosynthesis, Signal Transduction, Action!. Netherlands: Kluwer academic 
publishers.

Ellis, D. D., H. Barczynska, B. H. McCown and N. Nelson. (1991). A Comparison of BA, Zeatin, and Thidiazuron for Adventitious Bud Formation From Picea glauca Embryos and Epicotyl Explants. Plant Cell, Tissue and Organ Culture, Volume 27, Number 3, 281-287

George, E. F., and P. D. Sherrington. (1984). Plant Propagation by Tissue Culture. England: Exegetics limited.

George, E. F. (1993). Plant Propagation by Tissue Culture, Part 1, 2nd Edition. England: Exegetic Limited.

George, E. F., M. A. Hall, and G. J. De-Klerk. (2008). Plant Propagation Tissue Culture 3rd Edition. Netherlands: Springer.

Hadad, Usman Daras, dan Agus Wahyudi. (2007). Jambu Mete: Perbenihan dan Budidaya Pendukung Varietas Unggul. Bogor: Pusat Penelitian dan Pengembangan Perkebunan.

Kozlowski, T., T. (1971). Growth and Development of Trees Volume 1 Seed Germination, Ontogeny, and Shoot Growth. New York: Academic Press.

Mariska, I., dan R. Purnamaningsih. (1997). Perbanyakan Vegetatif Tanaman Tahunan Melalui Kultur In Vitro. Bogor: BALITBIO.

Nguyen, T., B., T., S. Ketsa, dan O. G. van Doorn. (2003). Relationship Between Browning and the Activities of Polyphenol Oxidase and Phenylalanine Ammonia Lyase in Banana Peel During Low Temperature Storage. Postharvest Biology and Technology, 30: 187/193

Tumilisar, Christiani dan R. Yunita. (2009). Perbanyakan Klonal Tanaman Jambu Mete (Anacardium occidentale L.) Melalui Jalur Embriogenesis Somatik dan Organogenesis. Program Kerjasama Penelitian Pertanian dengan Perguruan Tinggi KKP3T

Wattimena, G., A. (1987). Zat Pengatur Tumbuh Tanaman. Bogor: Laboratorium Kultur Jaringan Tumbuhan, PAU Bioteknologi IPB.

Wattimena, G., A. (1988). Zat Pengatur Tumbuh Tanaman. PAU IPB. Bogor

Wong, Melvin. (2006). Mature Leaf Chlorosis and Necrosis. Landscape: L-15

Zaubin, R., dan R. Suryadi. (2003). Budidaya Jambu Mete (Anacardium Occidentale L.). Circular 6: 1-8. 